Светлана Ж. Бабовић Универзитет Црне Горе

Филолошки факултет

Студијски програм за руски језик и књижевност
УДК: 821.161.1-84.08:821.163.41-84.08 https://doi.org/10.18485/uzdanica.2020.17.2.10

Оригинални научни рад Примљен: 30. септембар 2020. Прихваћен: 21. децембар 2020.

\title{
КОНЦЕПТ ЧАСТИ У ПОСЛОВИЦАМА РУСКОГ И СРПСКОГ ЈЕЗИКА
}

$A \bar{u} c \bar{u} p a \kappa \bar{u}:$ Предмет овог истраживања представљају руске и српске пословице ексцерпиране из зборника руских пословица В. И. Даља и зборника српских пословица В. С. Караџића које улазе у концепт части, који се сматра једним од важнијих етнокултурних концепата у руској и српској лингвокултури. Да би национално-специфични концепти били схваћени и упоређивани, потребно их је посматрати макар у два различита језика. Сходно томе, примарни задатак овог рада је реконструкција концепта части и издвајање лингвокултуролошких особености у поимању части код руског и српског народа. Методом концептуалне анализе руских и српских пословица покушаћемо да укажемо на сличности и разлике у поимању части код говорника руског и српског језика, а будући да се анализа врши на корпусу два језика, користићемо се и методом компаративне анализе. Анализа за крајњи циљ има откривање лингвокултуролошке, као и естетске вриједности руских пословица и њихових преводних кореспондената и њихово мјесто у језичкој слици свијета два посматрана блискосродна народа.

Кључне ријечи: концепт, пословица, част, лингвокултурологија, микроконцепт, образ, руски језик, српски језик.

\section{1. УВОДНА РАЗМАТРАҢА}

1.1. Културно богатство, историја, национални карактер и стереотипи су најјасније и најпотпуније представљени у пословицама, које чине такве језичке јединице у оквиру којих културна и фолклорна компонента игра главну улогу. Будући да је језик огледало културе, у њему је приказан не само реални свијет и реални услови његовог живота, него и друштвена самосвијест народа, његов менталитет, национални карактер, начин живота, традиција, обичаји, морал, систем вриједности, однос и представа о свијету. Управо зато језик треба да се изучава на нераскидивој вези са свијетом и културом народа који говори тим језиком.

ruskimir.niksic@gmail.com 
Национална специфичност пословица најбоље се испољава при конфронтацији различитих језика. Управо та конфронтација показује колико заједничког имају народи чије се пословице пореде и на тај начин доприносе узајамном разумијевању и зближавању тих народа. С обзиром на то да су српски и руски народ доста слични, да припадају истој онтолошкој матрици, са правом се може очекивати да разлике у оквиру посматране концептуалне анализе нису велике. Међутим, с обзиром да Руси и Срби живе у различитим социјалним и природним условима, имају различиту историју, културу и обичаје, лингвокултуролошком анализом указаћемо и на одређене специфичности једног или другог народа, а самим тим и његовог језика.

1.2. Када говоримо о концептуалној анализи, потребно је указати на сам термин концей $\bar{u}$, који се сматра кључним појмом когнитивне лингвистике, а у савременом значењу се употребљава тек од средине 20. вијека. Теоријске основе концепта у руском језику поставили су познати лингвисти С. А. Аскољдов, Н. Д. Арутјунова, Д. С. Лихачов, Ј. С. Степанов, В. В. Колесов, В. И. Карасик, В. А. Маслова, Ј. Д. Апресјан и други.

Термин концепт, у значењу менталне творевине, која у мисаоном процесу може да замијени мноштво предмета, поступака и мисаоних функција исте класе, први пут је употријебио А. Аскољдов (1997: 267).

У лингвистици је термин концепт постао општеприхваћен од почетка 90-их година, захваљујући научним радовима Д. С. Лихачова и Ј. С. Степанова. Иако Лихачов у свом раду Концептосфера русского языка (1997) износи позитивно мишљење о новаторском чланку С. А. Аскољдова, насупрот њему, он сматра да концепт не постоји само за ријеч, већ за свако основно речничко значење ријечи одвојено. Као зачетник лингвокултуролошког приступа у оквиру концептуалне анализе, Лихачов концепт разматра као основну јединицу културе, као алгебарски скуп значења, које човјек користи у свом говору (Лихачов 1997: 281). Његово име посебно је значајно због увођења термина концейтиосфера, под којом аутор подразумијева скуп концепата једне нације. Он сматра да је „концептосфера националног језика утолико богатија колико је богата читава култура нације - њена књижевност, фолклор, наука, ликовна умјетност, концептосфера је корелативна са читавим историјским искуством нације и религије посебно” (Лихачов 1997: 283).

J. С. Степанов у књизи Константыл. Словарь русской культуры (1997) концепт дефинише као оперативну јединицу културе, као творевину културног садржаја у људској свијести, као идеју која подразумијева апстрактна, конкретно-асоцијативна и емоционално-евалуативна обиљежја, као сажету историју самог концепта. Аутор сматра да посредством концепта човјек сам доспијева у културни простор, а понекад и врши утицај на њега (Степанов 1997: 267). Ј. Д. Апресјан (2006: 35) пише о томе да мјесто које неки концепт заузима на скали лингво и етноспецифичности може бити различито. По његовом мишљењу, што је арсенал средстава којима се концепт у неком 
језику изражава већи у односу на друге језике, што је природа тих средстава разноврснија, то концепт постаје етноспецифичнији и представља вишепланску појаву која се истовремено јавља на плану језика, културе, као и саме свијести човјека.

У монографији Фразеолоїија Горской вијенца (2010) Ана Пејановић такође пише о појму концейти. По њеном мишљењу, „концепт укључује појам, али се не исцрпљује само њиме, већ обухвата сав садржај језичке јединице, и денотативно и конотативно значење, у њему се одражавају оне представе носилаца одређене културе о појави која стоји иза ријечи у читавом спектру асоцијативних веза" (Пејановић 2010: 124).

При анализи одређеног концепта посебно је важан лингвокултуролошки приступ описа концепта (представници овог приступа, који концепте посматрају као елементе националне културе, између осталих су J. С. Степанов, В. И. Карасик, В. А. Маслова, Н. Ф. Алефиренко, С. Г. Воркачев, В. Г. Костомаров, Ј. Е. Прохоров, В. В. Воробјев и други), чији је основни циљ да истражи на које начине се језик манифестује у својим јединицама, чува и преноси културу. Другим ријечима, лингвокулторолошки приступ заснован је на тежњи да се објасни на који начин, и у којој мјери, култура учествује у формирању језичких концепата, или, постоји ли у стварности културно-језичка компетенција носилаца језика.

О значају национално-специфичних обиљежја у оквиру лингвокултуролошког проучавања писала је и 3. В. Сикевич. По њеном мишљењу, пословице представљају специфични језички материјал, у којем су акумулиране особености националне културе, историје, свакодневног живота, митске и друге појаве (Сикевич 1999: 197). Ана Пејановић запажа да је језик, као саставни дио културе, истовремено и њено оруђе. По њеном мишљењу, култура сваког народа вербализује се у језику, и управо језик акумулира кључне концепте културе, врши њихову транслацију и оваплоћује их у знакове - ријечи и друге језичке јединице (Пејановић 2010: 124).

\section{2. КОНЦЕПТ ЧАСТ}

Концепту части у руском језику посвећен је велики број радова, било да се ради о објективизацији концепта у једном језику, или кроз поређење са другим језицима (види у: Терина 2007; Ткаченко 2005). У српском језику овај концепт између осталих прочавали су А. Пејановић $(2008,2009,2010)$, С. Ристић (2015), Т. Милосављевић (2019).

Ана Пејановић сматра да је концепт части један од кључних етнокултурних концепата у фразеолошкој слици свијета говорника српског језика

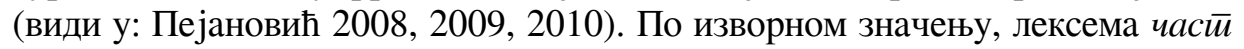
је апстрактна именица из сфере морала која припада интелектуалној човје- 
ковој дјелатности (Ристић 2015: 153). Бавећи се вербализацијом концепта час $\bar{u}$ код Куча, Тања Милосављевић пише да је концепт части комплексни когнитивни конструкт, базиран на спољашњем (социјалном) принципу који подразумијева спољашњу регулацију односа наметнуту од стране заједнице и унутрашњем (интимном) принципу, у оквиру којег концепт части одражава личну човјекову одговорност према моралним нормама (Милосављевић 2019: 272).

\section{1. О СЕМАНТИЦИ И ЕТИМОЛОГИЈИ ЛЕКСЕМЕ ЧАСТ}

Анализом значења лексема честь у руском, односно части у српском језику, забиљежених у речницима, дошли смо да закључка да је наведена лексема у оба језика вишезначна.

У већини речника руског језика част̄ се дефинише као скуп морално-етичких људских начела као што су поштовање, уважавање, честитост (почёт, почтение, уважение, честность, порядочность, добросовестность) (Ожегов, Шведова 2006: 882; Шведова 2008: 1090; Кузнецов 2000: 1477; РСРКЈ 1965: 983-991; Даљ 2007: 396; САР 2006: 725; Ушаков 2000: 1268). Важна интерпретација части у речницима односи се на морално или социјално достојанство (достоинство), које подразумијева изражавање поштовања одређене јединке према самој себи или изражавање поштовања од стране других (САР 2006: 726), а аутори појединих речника, у зависности од социјалног статуса човјека, говоре о сталешком, грађанском и професионалном достојанству (РСРКЈ 1965: 983-991). Осим наведених, у појединим речницима постоји и интерпретација части као репутације, угледа, доброг гласа о некоме (Ожегов, Шведова 2006: 882; Шведова 2008: 1090; Кузнецов 2000: 1477; РСРКЈ 1965: 983-991); као чина, високог звања, положаја (САР 2006: 725-726; Даљ 2007: 396; РСРКЈ 1965: 983-991).

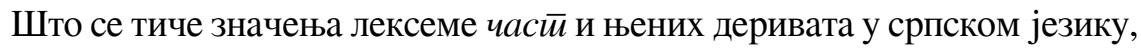
ми ћемо се у овом раду послужити концептуалном структуром части коју је приредила Стана Ристић (2015: 155-156), а која је састављена на основу грађе из историјског Рјечника ЈАЗУ и из Речника МC:

1. Као прво значење лексеме части наводи се признање, репутација коју неко или нешто има, задобија у друштву, јавности; иасйан' који је почаствован, што је почаствовано'; који некоме чини част'; 2. према подацима из речника, част означава високи службени положај, почасно угледно звање; 3. част представља и одређени начин понашања, опхођења: а) поступак, церемонија, обред; б) перфоматив у говорним чиновима: 1) исказивање части у представљању, поздрављању, ословљавању; 2) оцјене; 3) заклињања; 4) (иронично) грдње, вријеђања; 4. част се може схватити и као нешто конкретно чиме се указује пажња, уважавање а) гозба; б) дар, поклон; 5. последње зна- 


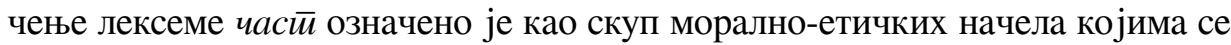
ко руководи у својим друштвеним и личним поступцима, поштење (види у: Ристић 2015).

Када је ријеч о етимолошком значењу, речници указују на општесловенско поријекло руске лексеме честь, о чему свједоче називи за ову лексему у осталим словенским језицима: пољ. cześć, чеш. čest, укр. честь, бјелор. чеcu, , буг. чест, срб́. ча̂с $\bar{u}$, словен. čâst, слов. с̌est'. Лексема честь образована је од прасловенског иьсть, који је етимолошки близак глаголу иьсти у значењу nочитать (поштовати, цијенити) (Фасмер 1987: 350). Да лексема потиче од прасловенског инфинитива *čisti са значењем 'сматрати, цијенити, мислити', потврђује и етимолошки речник српског језика П. Скока у којем се наводи

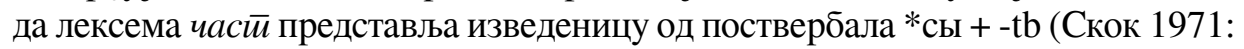
298).

\section{3. ПРЕГЛЕД ГРАЂЕ}

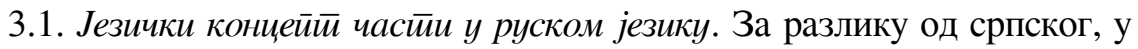
руском паремиолошком фонду потврђене су пословице које говоре да част може да посједује свако, без разлике у социјалном или материјалном положају. Ово значење потврђено је у 7 примјера из корпуса, при чему већи број (њих 6) указује на то како се сиромашан човјек односи према части:

Хоть мошна пуста, да душа чиста (Даљ 2009: 447); Гол, да не вор; веден, да честен (Даљ 2009: 447); Что за честь, коли нечего есть (Даљ 2009: 446); Честь добра, да съесть нельзя (Даљ 2009: 446); Нелюба и честь, как нечего есть (Даљ 2009: 446); Хороша и честь и слава, а лучше того каравай сала (Даљ 2009: 446).

Наведени примјери показују да сиромашан народ највише цијени материјалне вриједности, а част за њих представља апстрактну, духовну појаву. Све ове пословице говоре да су сиромаси принуђени да мисле како да преживе, тако да су моралне вриједности стављене у други план.

Супротно овим пословицама, у корпусу је посвједочена само једна пословица која говори да је част највише присутна код племићког сталежа. То значење изражава пословица Чести дворянин не кинет, хоть головуика сгинет (Даљ 2009: 446).

По нашем мишљењу, наведена руска пословица свједочи о историјском времену, када се губљење части код племића сматрало тежим од смрти.

У зборнику пословица Даља наведене су и пословице у којима постоји чврста граница између појмова часй и слава, у оквиру којих се налази човјек који је свјестан своје вриједности, односно свог достојанства, али исти тај човјек није високо цијењен од стране других: По хозяину и собаке честь (Даљ 2009: 447); По посьльщцку и посланцу (гонцу) почет (Даљ 2009: 447); Честь 
честью, а славы нет (Даљ 2009: 448); Честь честью, а слава нехороша (Даљ 2009: 448).

Говорећи о значењу лексеме часй у различитим речницима, као посебно, издвојило се значење високи службени йоложај, йочасно, уіллеgно звање. У вези с тим, постоје пословице које говоре да је част својствена особи која је материјално обезбијеђена, која заузима високо мјесто у друштву, значајан положај: Каков сан, таков и почет (Даљ 2009: 446); По сану и почет (Даљ 2009: 446); Кого почитают, того и величают (Даљ 2009: 446).

У руским пословицама човјек који не зна достојанствено да се понаша поистовјећује се са глупим човјеком: Дураку мука, а умному честь (Даљ 2009: 446); Дадут дураку честь, так не знает, где и сесть (Даљ 2009: 448); На дурака чести (т.е. почету) не напасешься (Даљ 2009: 448); Припала было иесть, да не умел ее снесть (Даљ 2009: 448).

3.2. Језички концепт частии у српском језику има сложену структуру, те се с тога може издвојити неколико микроконцепата, тј. концепт часй се може посматрати као макроконцепт који обухвата више микроконцепата. У

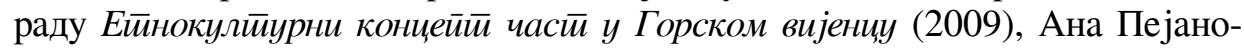
вић у оквиру макроконцепта часй, у чијем се центру налази микроконцепт образ, издваја још четири микроконцепта, које она назива „регулаторима патријархалног морала - очувања образа” а то су задата ријеч, дистанцирање и уклин, каменовање и крвна освета и умир (Пејановић 2009: 87). У овом раду посебну пажњу ћемо посветити лексеми образ, као основном лексичком представнику концепта часй.

У Речнику срйской језика Матице српске уз лексему образ, која има два значења - 1. једна страна лица; 2. фиг. част, поштење, понос - дат је већи број фразеологизама, при чему су објашњена и њихова значења: бацити образ под ноге изгубити, част, поштење; бити дебелог образа (имати дебео образ) немати осећања части и достојанства, немати стида ни срама; (о)каљати, (о)црнити образ (из)губити част, поштење; осветлати образ истаћи се неким часним делом, учинити нешто чиме се може поносити; црн ти образ (био)! срам те било, стиди се; човек од образа частан, поштен човек, човек којег треба ценити, поштовати (РСЈ 2011: 834).

Да лексема образ има пренесено значење, које упућује на вриједности

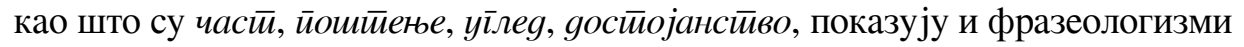
забиљежени у речнику Јосипа Матешића: чувати образ са значењем 'чувати/ очувати/спасити част/углед'; (од)бранити образ са значењем 'бранити част, углед'; изгубити образ са значењем 'изгубити поштење' (Матешић 1982: 403).

Ослањајући се на Ейимолошки рјечник словенских језика, Ана Пејановић истиче да лексема образ постоји у свим словенским језицима са различитим фонетским ликом, при чему етимологија наведене лексеме није довољно јасна (Пејановић 2009: 405). 
За разлику од српског језика, у којем је пренесено значење 'част', 'достојанство' стекла лексема образ, у руском језику ту функцију има лексема честь. То доказују и следеће пословице: За совесть, за честь - хоть голову с плеи (хоть голову снесть) (Даљ 2009: 446); Лучше глаза лишиться, чем доброго имени (Даљ 2009: 446); За честь голова гибнет. Честь головою оберегают (Даљ 2009: 447); Честь дороже жизни (Даљ 2009: 449); Бесчестье хуже (тяжеле) смерти (Даљ 2009: 449); Лучше смерть, нежели позор (Даљ 2009: 449); Смерть лучше бесчестья (Даљ 2009: 449); Лучше умереть с честью, чем жить с позором (Даљ 2009: 449); Хоть плетьми высоки, только чести не лишай (Даљ 2009: 449).

Један од кореспондената ових пословица у српском језику је Чоек све gава за образ, а образ ни за шито (Караџић 1987: 305).

Као варијанте ове пословице, Ј. Ж. Гиљотен наводи сљедеће: Све за

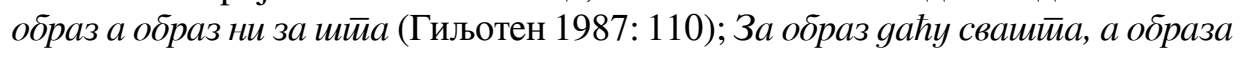
(не gам) ни за шима (Гиљотен 1987: 73).

Као што је очигледно, ове пословице представљају варијанте Вукове пословице. Оне заједно чине деривацијске скупове са заједничким лексичким језгром (види у: Јовановић 2006 I: 263). У свакој од наведених пословица, које уједно потврђују и појаву пословичке синонимије, тематско (лексичко) језгро представља лексема образ, која се вреднује путем одговарајућих имплицитних поређења. Наведене пословице, како у руском, тако и у српском језику, говоре о човјеку који је спреман за част и да погине, тј. и код руског и српског народа губитак части се сматра горим од саме смрти.

Вук Караџић је у својој збирци забиљежио велики број народних умотворина у којима је садржана лексема образ. Такође се овим умотворинама, које као главни тематски стожер садрже лексему образ, бавила и Јелена Јовановић (види у: Јовановић 2006 II: 63).

Сада ћемо навести пословице ексцерпиране из зборника Вука Караџића са лексемом образ:

1. Ђе је образ йу је и яуша (Караџић 1987: 98); 2. Ко има образа има и gушу (Караџић 1987: 147); 3. Ко у небо йљује, на образ му йаgа (Караџић 1987: 161); 4. Kag чоек наgа се йльне, на образ ће йасйи (Караџић 1987: 134); 5. Ко више себе йљује, на образ му йаgа (Караџић 1987: 144); 6. Плуни врх себе, каg ли на образ (Караџић 1987: 230); 7. Не іори образ оg сунца, већ оg йошйенијех љуяи (Караџић 1987: 190); 8. Образ оg образа сииияи се (Караџић 1987: 215); 9. Нишйа се с образом није измијешало (Караџић 1987: 212); 10. Ако је и gоцкан, али је с образом (Караџић 1987: 326); 11. Чисйу образу мало воgе йреба (Караџић 1987: 305); 12. Воgа свашйо ойере gо ирна образа (Караџић 1987: 70); 13. Рука руку йере, а образ обаgвије (Караџић 1987: 248); 14. Og gва лица образ не може бийи (Караџић 1987: 332).

У пословицама 1 и 2 очигледна је веза моралних и емоционалних вриједности. Ове пословице говоре о томе да је моралан човјек истовремено 
и добар човјек. Осим тога, уз прву пословицу, која садржи лексему gуша,

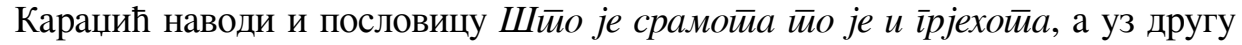
пословицу Караџић упућује на још једну пословицу - Ко се љуgи не cūugu, ни Боїа се не боји. У пословицама на које упућује Караџић заправо се истичу

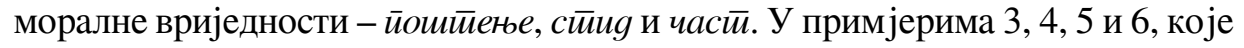
представљају варијанте, а које су проистекле из пословице Ко у небо йљује, на образ му йaga, описан је однос човјека према друштвеним силама. О овој групи писала је и Јелена Јовановић, која сматра да се овим пословицама препоручује суздржаност у осуди јачих, тј. извјесна морална толеранција, чак прагматична беневолентност према сили (Јовановић 2006 I: 263). Уз пословицу Ко више себе йљује, на образ му йаgа, Караџић даје појашњење (каg

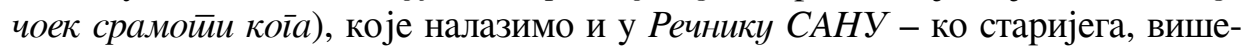
га, значајнијега од себе клевеће, сам себе унижава (РСАНУ XVI 2001: 403). Слично објашњење уз пословицу Kag чоек наgа се йљуне, на образ ће йасйи даје и Иван Димитријевић у својој докторској дисертацији: „Кад човек крене да чисти (пљуне) неког часнијег (вишег) од себе, сам се морално упрља, па на крају мора да пере (пљуне) себе" (Димитријевић 2015: 422). У пословици

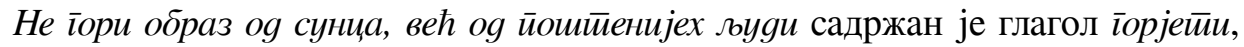
који заправо указује на лице које црвени, тако да у наведеној пословици, која говори о угледу, лексема образ упућује на осјећање стида. Пословицом образ оg образа сйиgи се, како сам Караџић истиче, описује се велики стид или срамота. У пословицама Нишйа се с образом није измијешало и Ако је и gоцкан, али је с образом, образ, који има јако морално значење, представљен је и као идеал који је изнад свих вриједности, он се не може поредити ни са чим. У примјерима 10, 11 и 12, у којима је присутан денотат чисйойа, односно чисй, јавља се лустративна течност у виду воде која представља вид симболичног очишћења од прљавштине, гријеха. У оквиру ове групе пословица прве двије се могу на неки начин сматрати антонимским, јер с једне стране имамо пословицу Чистиу образу мало воgе йреба, која говори о часном чо-

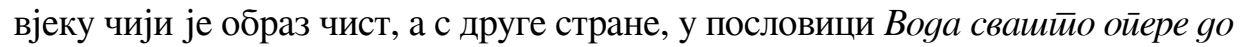
црна образа говори се о злом, неморалном, непоштеном човјеку (Караџић 1987: 70), црн образ се супроставља чистом образу. У пословици Рука руку иере, а образ обаgвије истиче се „поштење као предмет колективне етике, односа индивидуе према другима, јер тек у садејству субјекта и његовог окружења, метафорички обеју руку, појединац стиче част, чист образ као награду за поштено делање; а да би до тог садејства (договора) дошло, нужно је да се обе стране 'умију', прочисте, отарасе нечистоће" (Димитријевић 2015: 184). Последња пословица, Og gва лица образ не може бийи говори о дволичности, тј. да човјек који је дволичан не може бити и поштен (PCAHУ XVI 2001: 403).

Овдје ћемо истаћи и мишљење Ане Пејановић да се фразеолошке јединице са лексемом образ могу сврстати у два опозитна низа. Она пише: „У једном се низу налазе оне фразеолошке јединице које одражавају друштвено 
прихватљиво, пожељно понашање, идеал, оно за шта народ каже 'ваља се'. Други пак низ садржи јединице супротне семантике, а оне су одраз непожељног, неприхватљивог, анатемисаног, онога за шта народ каже 'не ваља се"” (Пејановић 2009: 410). У истом раду она разматра фразеологизме кроз три различите опозиције, и то као метафоре: бијело-црно, врх-дно, и меко-тврдо (Пејановић 2009: 410-412).

Ойозиција бијело-ирно. По мишљењу Ане Пејановић, ова опозиција је примарна и најважнија, јер се на њој заснива већи број фразеолошких јединица: од идиома, преко благослова и клетве који су у центру концепта, до изрека, пословица, узречица и заклетви (Пејановић 2009: 410). По њеном мишљењу, црн образ као крајња посљедица кршења етичких начела заједнице, који агенс може да стекне сам својим чињењем или нечињењем, или му неко други нанесе моралну штету, оскрнави достојанство, не мора такав остати једном за свагда (Пејановић 2009: 408-411).

Опозиција бијело-ирно је заступљена и међу нашим примјерима: Чи-

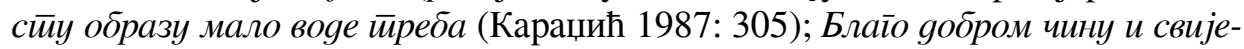
йлом образу (Караџић 1987: 54); Воgа свашӣо ойере gо ирна образа (Караџић 1987: 70); Поцрнио му образ ка’ и ниийа чоеку (Караџић 1987: 236).

Ойозиција врх-gно. Ова опозиција је заступљена у идиому Мейнуйи образ йog нойе (Караџић 1987: 176) и пословици Ко у небо йљује, на образ му üaga (Караџић 1987: 161) и њеним варијантама Кag чоек наgа се йљуне, на образ ће йасйи (Караџић 1987: 134); Ко више себе йљује, на образ му йаgа (Караџић 1987: 144); Пљуни врх себе, каg ли на образ (Караџић 1987: 230).

Ослањајући се на Речник САНУ, Ана Пејановић у претходно помену-

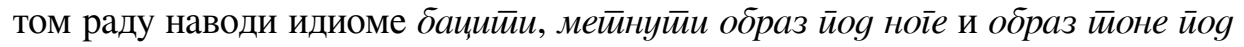
очи. Поред ових, она наводи примјер ексцерпиран из зборника пословица Ђуре Даничића (П’о му образ на земљу) и ускочког речника Милије Станића

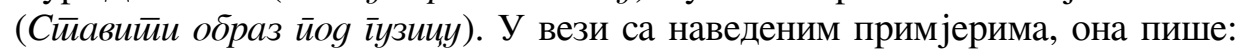
„Занимљив је 'пад' образа по вертикали: од образа на висини, што је идеал, до образа који је пао на земљу (остали 'нивои' одређени су соматизмима: очи, $\bar{\imath} y з и ц$, ноге, који су фиксирани у саставу фразеологизама и илустрација су антропоцентричности језика)" (Пејановић 2009: 411).

Ойозиција йвpg-мек. Ова опозиција је најчешће заступљена у идиомима и устаљеним поређењима. Устаљена поређења са овом опозицијом налазимо и у зборнику Караџића: Кожа му је на образу као ђон (Караџић 1987: 146); Кожа му је на образу йврgа као у вола (Караџић 1987: 146); Образ му је као ойанак (Караџић 1987: 215).

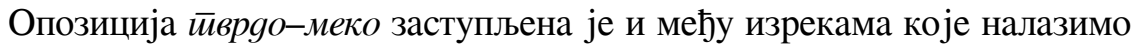
код Вука Караџића: Девети чарайа има на образу (Караџић 1987: 17); Мекообразној ђевојии йрбух gо зуба (Караџић 1987: 86).

Ове изреке разматрала је и Ана Пејановић, при чему закључује да

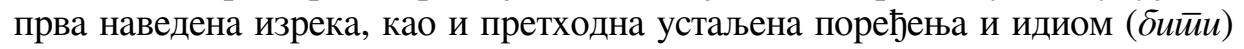


gебела образа (ексцерпиран из Речника САНУ) стоје у антонимском односу

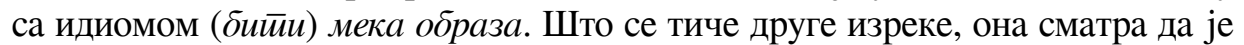

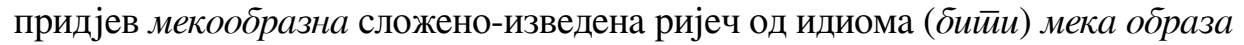
који има афирмативну семантику (Пејановић 2009: 411).

3.3. На основу речничког корпуса концептуализације значења лексеме час $\bar{u}$, за разлику од руског, у српском језику једно од значења лексеме часй је чашћење, гозба, гошћење, као и част у виду дара, поклона у јелу, пићу или новцу које донесу званице на свадбу. О томе пише и Стана Ристић (2015:

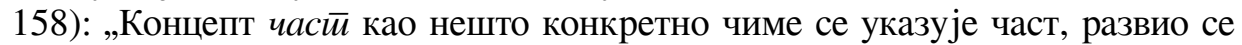
на основу метонимијског преношења апстрактног значења вредновања на пропратне поступке и предмете који су често допуњавали церемонијал указивања части."

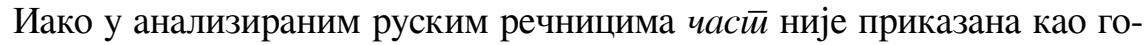
зба, дар, поклон, у пословицама руског језика концепт иасиии добија посебно оличење при активирању обредних, односно ритуалних компонената. Једна од главних ритуалних компонената је $\bar{\imath} о \bar{u} о \bar{u} р и м с \bar{u} в о$, које подразумијева дочек гостију, одавање одређених почасти, гошћење у оквиру богате трпезе, као и великодушан и љубазан однос према гостима. О томе свједоче следеће пословице: Гостю почет - хозяину честь (Даљ 2009: 508); Честь гостю приложена, а убытку Бог избавил (Даљ 2009: 509); Встречай гостя не с лестью, а с иестью (Даљ 2009: 508); Не спрашивают: чей, да кто и откуда, а садись обедать (Даљ 2009: 512); Про гостя хороше, а про себя поплоше (Даљ 2009: 512); Честно величать, так на пороге встречать (Даљ 2009: 515); Принимают, за обе руки берут да в красный угол сажают (Даљ 2009: 508).

Да је ријеч о типично руским пословицама нарочито се види на основу последња два примјера. У једном од њих изражена је синтагма на пороге встречать, а иначе је за руску лингвокултуру општепознато да прави и гостољубиви домаћин сријеће госте на прагу. Последња пословица садржи руску реалију краснылй угол. У бројним речницима, а уопште и у свијету је познато да се под овом руском реалијом сматра просторија у којој се налазе иконе и сто, а за тим столом могли су да сједе само они који су заслуживали дубоко поштовање и част. У наведеним руским пословицама представљен је стереотип великодушног и гостопримног домаћина, а иначе је познато да је гостопримство „својствено менталитету балканских народа у чијим се културним традицијама прожимају елементи словенске и оријенталне културе дочекивања гостију и угошћавања, при чему посебно место заузима фрејм хране" (Милосављевић 2019: 45).

У српском паремиолошком фонду карактер срдачног гостољубивог домаћина осликавају пословице које углавном говоре о богатој трпези: Коме не било овђе, не било му ниіђе (Караџић 1987: 89); Као у кума на часйи (било

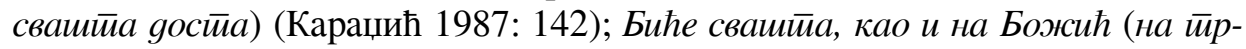
йези) (Караџић 1987: 53). 
У паремиолошком фонду оба језика постоје пословице, контрадикторне наведеним, које говоре о негостољубивом домаћину: Звали гостей, да посадили глодать костей (Даљ 2009: 404); Звал на честь, а посадил на печь (Даљ 2009: 447); У него гостят четыре угла (никого) (Даљ 2009: 516); Дозвао

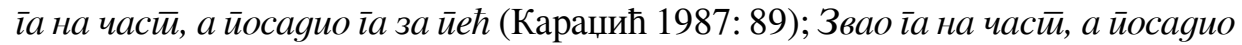

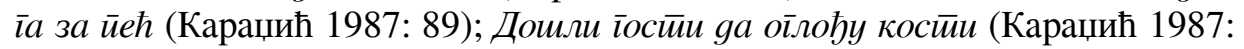

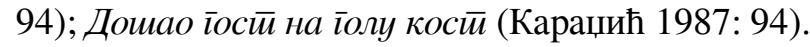

Бавећи се концептом гостопримства у језичком сазнању српског на-

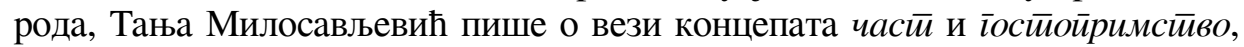
у чијем се центру налази $\bar{\imath} о c \bar{u}$, као централна фигура гостопримства, при чему она појам госта везује за „особу која долази коме у походе да проведе извесно време код њега, за лице које је позвано на обед или какву другу част, из чега произлази да је за носиоце српског језика прототип госта звани гост (званица), жељени гост коме се указује посебна част, обично у храни и пићу” (Милосављевић 2019: 45-46).

На основу претходних пословица можемо закључити да се у оквиру

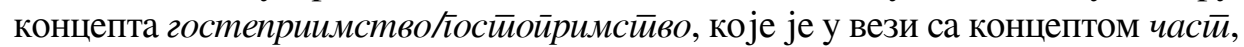
у руском и српском језику могу издвојити лексеме које представљају субјекат и објекат гостопримства. У функцији субјекта у руском језику користи се лексема хозяин, а у српском језику тој лексеми одговара ријеч gомаћин. Функцију објекта гостопримства у руском и српском језику имају лексеме гость/лос $\bar{u}$, мада осим ове лексеме у српском језику постоје и следеће: званица - приглашенньіи, званьий гость; намерник - случайно пришедший, случайньлй гость; уљез - незваньй гость, пришелеи (Срйске славе и верски обичаји 2003: 73).

Прототип званоі $\bar{\imath} о \bar{u} a$ у руском и српском паремиолошком фонду изражавају следеће пословице: Желанный гость зову не ждет (Даљ 2009: 505); Зван іостиован (Караџић 1987: 108); Зван као иошћен (Караџић 1987: 108); Зван йошйован (Караџић 1987: 108); Зван ирибран (Караџић 1987: 108); Кума нуђена као и чашћена (Караџић 1987: 165).

За разлику од прототипа госта као званог, у руским и у српским пословицама је чешће заступљен стереотип нежељеної $\bar{\imath} \bar{u} a$, што се не подудара са представом о гостољубивости словенског народа.

Незван гость, непасена и честь (Даљ 2009: 512); Незванные гости гложут и кости (Даљ 2009: 517); На незвана гостя не пасена и ложка (Даљ 2009: 515); Бесстьžего гостя из избы пивом не выгонишь (Даљ 2009: 448);

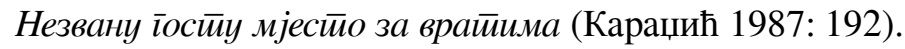

Осим наведених пословица, и у руској и у српској лингвокултури постоји негативна представа о незваном, злом госту, који се у оба језика поистовјећује са крвним непријатељима руског, односно српског народа, тј. гост се у руском језику пореди са Татарином, а у српском са Турчином: Незваный гость хуже Татарина (Даљ 2009: 517); Не вовремя (Не в пору) гость хуже 
Татарина (Даљ 2009: 512); Нема зиме без вјейра, ни зла іостйа без Турчина (Караџић 1987: 195).

\section{4. ЗАКЉУЧНЕ НАПОМЕНЕ}

С обзиром на то да руски и српски језик (а самим тим и народ) припадају истој онтолошкој заједници, да су доста слични, очекивало се да ће добијени резултати у оквиру нашег истраживања показати и велику сличност у погледу паремиолошког фонда посматраних двају језика. Ова претпоставка је већим дијелом и доказана. У оба језика постоје пословице које говоре колико је част, поштење и достојанство важно за припаднике једног или другог народа. С друге стране, познато је да Руси и Срби ипак живе у различитим социјалним и природним условима, имају различиту историју, културу, обичаје, те смо стога, у оквиру нашег истраживања, дошли до закључка да паремиолошки фонд наведених упоређиваних језика садржи и неке специфичности својствене само једном од тих језика. Сагледавајући пословице које улазе у концепт час $\bar{u}$, као главно обиљежје српског паремиолошког фонда (а самим тим и српског народа), уочили смо да је у пословицама изражено доминантно истицање и величање образа, који је представљен као идеал, као вриједност којој човјек тежи и за коју је спреман и живот да изгуби. У руском језику смо, насупрот овоме, нашли мали број пословица у овом значењу, и при томе уочили да достојанство и поштење различито доживљавају припадници различитих друштвених и социјалних сталежа. На основу анализираних пословица закључили смо да пословице које припада-

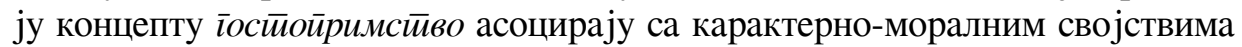
личности као што су част, поштење, љубазност. Како у руским, тако и у српским пословицама заступљени су модели понашања и односа према званим и жељеним гостима с једне стране, и незваним, нежељеним с друге.

\section{ИЗВОРИ}

Гиљотен (1987): Ј. Ж. Гиљотен, Срйскохрвайско-руски йаремиолошки речник, предговор Радмило Маројевић, Београд: Славистички зборник.

Даљ (2009): В. И. Даль, Пословицы и поговорки русского народа, Москва: Эксмо.

Караџић (1987): В. С. Караџић, Срйске нароgне йословице (приредио Мирослав Пантић), Београд: Просвета. 


\section{ЛЕКСИКОГРАФСКИ ИЗВОРИ}

Даљ (2007): В. И. Даль, Толковый словарь живого великорусского языка, в 4 т. Т. 4, Москва: ОЛМА Медиа Групп.

Кузнецов (2000): С. А. Кузнецов, Большой толковый словарь русского языка, Санкт-Петербург: Норинт.

Матешић (1982): J. Matešić, Frazeološki rječnik hrvatskoga ili srpskog jezika, Zagreb: Školska knjiga.

Ожегов, Шведова (2006): С. И. Ожегов, Н. Ю. Шведова, Толковый словарь русского языка: 80000 слов и фразеол. выражений, Москва: [ИТИ Технологии].

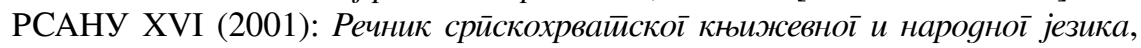
Београд: Институт за српски језик САНУ.

PCJ (2011): Речник срйскоїа језика (измењено и поправљено издање), Нови Сад: Матица српска.

САР (2006): Словарь Академии Российской, 1789-1794: в 6 т. Т.6 / РАН, Отдние лит. и яз., Моск. гуманитар. Инт-т им. Е. Р. Дашковой, Москва: МГИ им. Е. Р. Дашковой.

Скок (1971-1973): P. Skok, Etimologijski rječnik hrvatskoga ili srpskoga jezika, knj. prva, A- J, Zagreb: Jugoslovenska akademija znanosti i umjetnosti.

РСРКЈ (1965): Словарь современного русского литературного языка, Т. 17, Х - Я / АН СССР, Ин-т. рус. яз. / ред. Л. С. Ковтун, В. П. Петушков, Москва; Ленинград: Наука.

Ушаков (2000): Д. Н. Ушаков, Большой толковый словарь современного русского языка, Москва: „Издательство АСТ”.

Фасмер (1987): М. Фасмер, Этимологический словарь русского языка, Москва: Прогресс.

Шведова (2008): Н. Ю. Шведова, Толковый словарь русского языка с включением сведений о происхождении слов, Москва: Изд. Центр „Азбуковник”.

\section{ЛИТЕРАТУРА}

Апресјан (2006): Ю. Д. Апресян (отв. ред.), Языковая картина мира и системная лексикография, Москва: Языки славянской культуры.

Аскољдов-Алексејев (1997): С. А. Аскольдов, Концепт и слово, Русская словесность: от теории словесности к структуре текста, Антология, под. ред. проф. В. П. Нерознака, Москва: Языки русской культуры, 267-279.

Димитријевић (2015): И. Димитријевић, Вербализација концейт̄а часйи и йошиеиеь а у сииском језику, докторска дисертација, Нови Сад.

Јовановић (2006а): Ј. Јовановић, Књийа срйских наровних йословица I, Београд: Чигоја.

Јовановић (2006б): Ј. Јовановић, Книїа срйских народних йословица II, Београд: Чигоја.

Лихачев (1997): Д. С. Лихачев, Концептосфера русского языка, Русская словесность: от теории словесности к структуре текста, Антология, под. ред. проф. В. П. Нерознака, Москва: Academia, 280-287. 
Милосављевић (2019а): Т. Милосављевић, Вербализација концепта част на језичкој слици света Куча, Срйско језичко и књижевно насљеђе на йросйору gанашње Црне Горе. Срйски језик и књижевносӣ gанас, Зборник радова са Другог међународног научног скупа одржаног у Подгорици 26-28. маја 2017, Подгорица: Матица српска - Друштво чланова у Црној Гори.

Милосављевић (2019б): Т. Милосављевић, Концепт гостопримство у језичком сазнању српског народа (на примерима из Вукове грађе), Савремени йокови у науци о језику и књижевносиии, Тематски зборник радова, књ. 2, Ниш: Наука и савремени универзитет 8, 43-57.

Пејановић (2008): А. Пејановић, Етнокултурни концепт род у Горском вијенцу, Слависииика, књ. ХІІ, Београд: Славистичко друштво Србије, 298-308.

Пејановић (2009): А. Пејановић, Етнокултурни концепт част у Горском вијен-

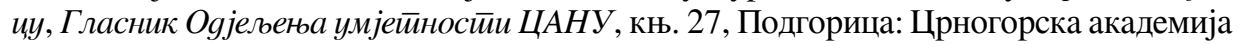
наука и умјетности, 85-101.

Пејановић (2009): А. Пејановић, Концептуални статус лексеме образ у срп-

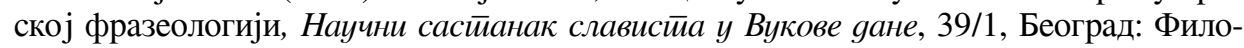
лошки факултет, 405-415.

Пејановић (2010): А. Пејановић, Фразеолог̄ија Горской вијенца: Фразеолошки жанрови. Кулйурни концеййи. Руски йревоgи, Подгорица: Црногорска академија наука и умјетности.

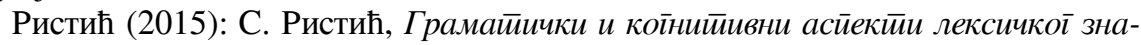
чень, Београд: Институт за српски језик САНУ.

Сикевич (1999): 3. В. Сикевич, Социология и психология национальньх отношений, Санкт-Петербург: Издательство Михайлова В. А.

Срйске славе и верски обичаји (2003): Шабац: Глас цркве.

Степанов (1997): Ю. С. Степанов, Константьл. Словарь русской культуры, Москва: Языки русской культуры.

Терина (2007): С. В. Терина, Древнерусский концепт честь и его языковая репрезентация в летописи „Повесть временных лет”, дис. канд. филол. наук, Тольятти.

Ткаченко (2005): О. В. Ткаченко, Феномен чести в европейской и русской культуре (философскоантропологический анализ), Ростов н/Д: Изд-во Северо-Кавказского научного центра высшей школы.

\section{Светлана Ж. Бабович}

Университет Черногории

Филологический факультет

Отделение русского языка и литературы

\section{КОНЦЕПТ ЧЕСТИ В ПОСЛОВИЦАХ РУССКОГО И СЕРБСКОГО яЗЫКОВ}

Резюме: Предметом этой работы являются русские и сербские пословицы, взятые из сборника русских пословиц В. И. Даля и сборника сербских пословиц В. С. Караджича, входящих в концепт честь, считающийся одним из важнейших 
этнокультурных концептов в русской и сербской лингвокультуре. Для того, чтобы национально-специфические концепты были поняты и сопоставлены, надо наблюдать за ними как минимум в двух разных языках. Соответственно, основная задача данной статьи - реконструкция концепта чести и выявление лингвокультурологических особенностей в понимании чести у русского и сербского народов. Используя метод концептуального анализа русских и сербских пословиц, мы попытались указать на сходства и различия в понимании чести носителей русского и сербского языков, а поскольку анализ проводится на корпусе двух языков, мы использовали метод сопоставительного анализа. Конечная цель анализа - выявить лингвокультурологическую, а также эстетическую ценность русских пословиц и их переведенных корреспондентов и их место в лингвистической картине мира двух наблюдаемых близкородственных народов.

Ключевые слова: концепт, пословица, честь, лингвокультурология, микроконцепт, совесть. 